\title{
Susceptibility of rice insect pests and their natural enemies to commonly used insecticides
}

\author{
S.H.P.P. Karunaratne ${ }^{*}$, K.C. Weerakoon ${ }^{1}$, L. Nugaliyadda ${ }^{2}$ and G.K. Manuweera ${ }^{3}$ \\ 1 Department of Zoology, University of Peradeniya, Peradeniya; Postgraduate Institute of Scic'nt Peradeniya. \\ Department of Agricultural Biology, University of Ruhuna, Matara. \\ 3 Office of the Registrar of Pesticides, Gatambe, Kandy.
}

Revised: 09 January 2007; Accepted: 14 February 2007

\begin{abstract}
Insect pests of rice are a major constraint in paddy cultivation in Sri Lanka. Control of insect pests heavily depends on the use of insecticides, for which the major threat has been the development of resistance. It is important to understand the present status of insecticide resistance in rice insects to identify the most suitable insecticides which are most effective against pests and least effective agaist their natural enemies.
\end{abstract}

Insecticide resistance and the underlying resistance mechanisms were studied in five rice insect pests (brown planthopper Nilaparvata lugens; green leafhopper Nephotettix virescens; paddy bug Leptocorisa oratorius; white planthopper Cofana spectra and white-back planthopper Sogatella furcifera), and four of their predators (lady-bird beetle Micraspis discolor; ground beetle Ophionea indica; mired bug Cytorhinus lividipennis and spider Tetragnatha sp.). Insects were collected from the rice fields at Batalagoda, Kurunegala district (intermediate zone) and Angunakolapalassa, Hambanthota district (dry zone) of Sri Lanka from 2001 to 2003. They were subjected to insecticide bioassays with dimethoate, chlorpyrifos, permethrin, carbosulfan and fenobucarb by topical application. Log-probit mortality lines and $\mathrm{LD}_{50} / \mathrm{LD}_{90}$ values were obtained. To determine the resistance/susceptibility against malathion, an organophosphate which has been heavily used in mosquito control programmes, and against DDT, an organochlorine which was the major insecticide used from early 1950 s to mid 1970 s, bioassays were conducted with malathion and DDT as well.

N. lugens collected from both sites showed high resistance to permethrin. $L$. oratorius population at Angunakolapalassa was resistant to carbosulfan compared to Batalagoda population. L. oratorius, $M$. discolor and Tetragnatha sp. populations at Angunakolapalassa were susceptible to permethrin compared to Batalagoda populations and Tetragnatha sp. population at Angunakolapalassa was susceptible to chlorpyrifos. Others from both study areas showed similar resistance levels. In general, most of the species tested from Batalagoda and Angunakolapalassa had lower tolerance for malathion while some species showed higher tolerance for DDT.

key words: Insecticide resistance, natural enemies, rice insect pests, Sri Lanka.

\section{INTRODUCTION}

Rice is the staple food in Sri Lanka accounting for about $45 \%$ of the per capita calories and $40 \%$ of the per capita protein consumption. Due to the introduction of high yielding varieties and use of fertilizers, the rice production in Sri Lanka increased substantially over the last forty years inspite of various biotic and abiotic stresses which reduce the yield significantly. Apart from the natural factors such as droughts and floods, the highest yield loss is due to insects and weeds.

Use of insecticides has become the most popular and the most efficient method of insect pest control. Although insecticides pollute the environment, they serve as an important tool in the management of insect pests especially during pest outbreaks. Once insecticides are sprayed, both pests and their natural enemies which play a major role in biological control of pest insects are affected. However, farmers prefer to use insecticides to control insect pests because of their high efficacy. Most farmers tend to use dosages which are higher than the recommended dosages, for better results. Continuous use and indiscriminate use of insecticides often cause insecticide resistance in pest populations resulting in pest resurgence. 
The present study was carried out to investigate and compare the insecticide cross-resistance spectra of five rice insect pests and some of their predators from two different rice growing areas of Sri Lanka, to some of the recommended insecticides.

\section{METHODS AND MATERIALS}

Study sites: The major study site was an irrigated rice field at the Rice Research and Development Institute, Batalagoda, Kurunegala district, located in the Intermediate zone of Sri Lanka, $7^{0} 30 \mathrm{~N}$ and $80^{\circ} 20^{\circ} \mathrm{E}, 100 \mathrm{~m}$ above the sea level (Figure1).

Studies were carried out from 2001 to 2003 and covered four consecutive rice cultivation cycles, including two Maha (October to March) and two Yala (April-September) seasons. Limited studies were carried out in the rice fields at the Regional Agricultural Research

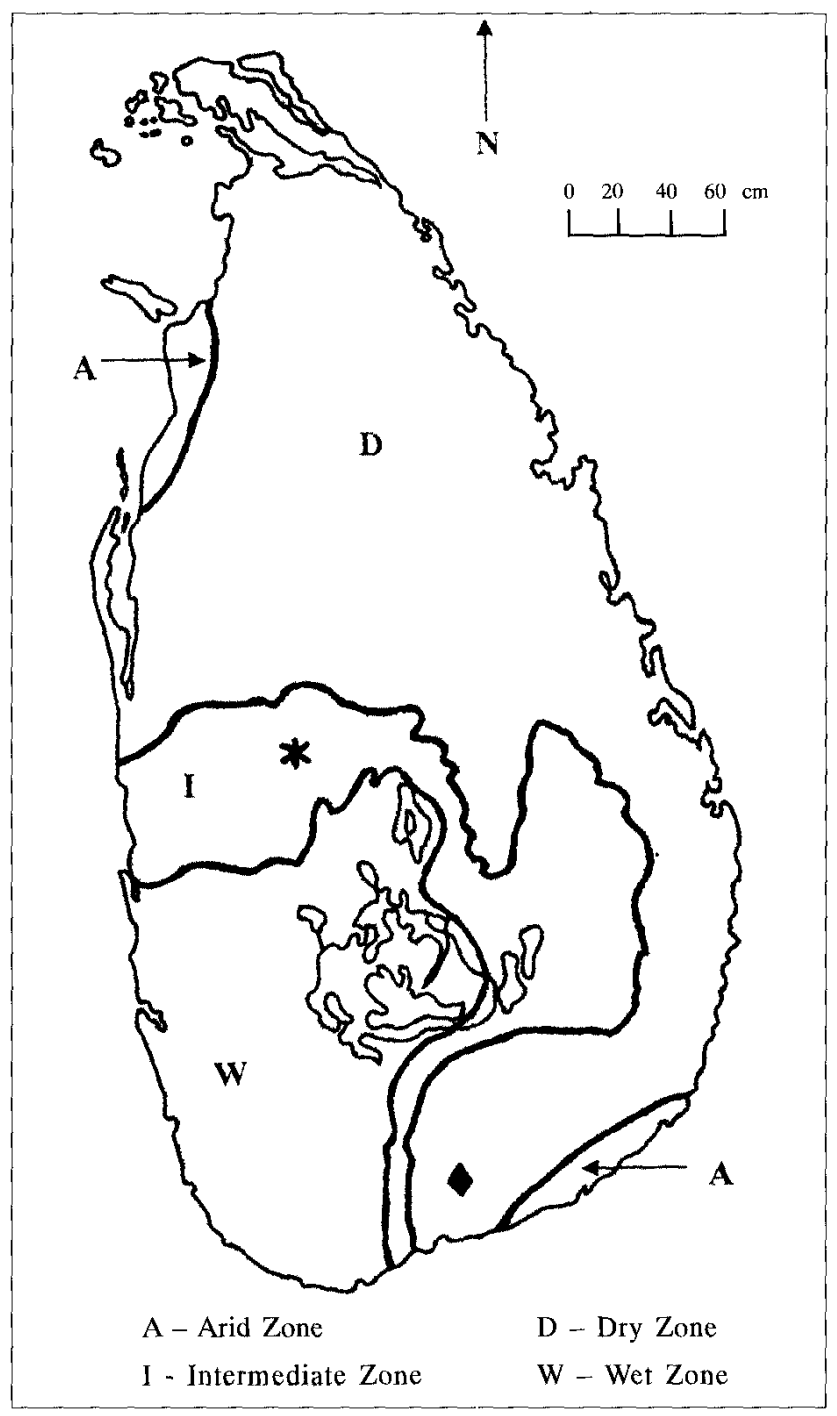

Figure 1: Study sites: Batalagoda (*) and Angunakolapelesssa ( and Development Center, Angunakolapelessa, Hambanthota district, located in the Dry zone of Sri Lanka, $6^{\circ} 28^{\prime} \mathrm{N}, 81^{\circ} 2^{\prime} \mathrm{E}, 30 \mathrm{~m}$ above the sea level (Figure 1). Studies at Angunakolapalassa were carried out in 2002.

Insects: Five species of adult rice insect pests namely Nilaparvata lugens (brown planthopper, Homoptera: Delphacidae), Leptocorisa oratorius (paddy bug, Hemiptera: Alydidae), Nephotettix virescens (green leafhopper, Homoptera: Cicadellidae), Sogatella furcifera (white-back planthopper, Homoptera: Delphacidae) and Cofana spectra (white planthopper, Homoptera: Cicadellidae); and four species of predators namely Micraspis discolor (ladybird beetle, Coleoptera: Coccinellidae), Ophionea indica (ground beetle, Coleoptera: Carabidae), Tetragnatha sp. (spider sp., Aranea: Tetragnathidae) and Cytorhinus lividipennis (mired bug, Hemiptera: Miridae) were collected from the rice fields using sweep-net and blower-vac methods.

Chemicals and equipment: Chemicals were purchased from Sigma, USA, unless otherwise stated. DDT ( $97.5 \%$ pure) and paraoxon (98\% pure) were from Greyhound, UK; malathion ( $97.5 \%$ pure) and chlorpyrifos ( $98 \%$ pure) were a gift from Cheminova, Denmark; propoxur (98.5\% pure) from Bayer, Germany and permethrin (98\% pure) from Aventis, UK; Dimethoate (96\% pure), fenobucarb ( $(97.5 \%$ pure) and carbosulfan $(90.81 \%)$ were a gift from AgroEvo (Ceylon), Sri Lanka.

Insecticide bioassays: Bioassays were carried out using the topical application method. A drop of the insecticide solution was applied topically on to the thoracic region of the insect using a microapplicator (Burkard, England) with a drop size ranging from $0.25 \mu \mathrm{L}$ to $1 \mu \mathrm{L}$. Insecticide stock solutions were prepared in acetone. Serial dilutions were made with acetone. Adrop of the insecticide solution was applied on to the dorsal surface of the thoracic tergites of each insect ${ }^{1-3}$. As recommended by the International Rice Research Institute (IRRI), $0.25 \mu \mathrm{L}$ was applied for planthoppers and leafhoppers. $0.5 \mu \mathrm{L}$ was used for the ground beetle and ladybird beetle. $1 \mu \mathrm{L}$ was applied for paddy bug and spider $^{1-3}$. Control experiments were done using acetone alone. Five to twenty five insects were used per assay and at least four replicates were used for each dosage. Treated insects were transferred into a clean vial containing food materials. Mortalities were recorded after a $24 \mathrm{~h}$ period. Data were analysed only when the mortalities of control experiments were $<20 \%$. Actual mortalities were obtained from the observed mortalities using Abbott's formula ${ }^{4}$.

Mortalities (probability scale) obtained with chlorpyrifos, dimethoate, carbosulfan, fenobucarb and permethrin were plotted against dosages (log scale) and 
$\mathrm{LD}_{50} \mathrm{LD}_{90}$ values were obtained by regression analysis. All test insect species were treated with a fixed dosage of $3.5 \mu \mathrm{g} / \mathrm{mg}$ (biomass) DDT and $4.4 \mu \mathrm{g} / \mathrm{mg}$ (biomass) malathion ${ }^{5}$. Only dosages resulting in $\mathrm{LD}_{50}$ and $\mathrm{LD}_{90}$ with the Batalagoda species and the fixed DDT and malathion dosages, were tested against Angunakolapalassa species.

Table 1: $\mathrm{LD}_{50}{ }^{*}$ and $\mathrm{LD}_{90}{ }^{* *}$ ( $\mathrm{kg} / \mathrm{g}$ insect body weight) values of unsecticides for the insect pest populations at Batalagoda as determined by the toprcal application method

\begin{tabular}{|c|c|c|c|c|c|c|c|c|c|c|}
\hline \multirow{2}{*}{ Species } & \multicolumn{2}{|l|}{ Dimethoate } & \multicolumn{2}{|l|}{ Chlorpyrifos } & \multicolumn{2}{|l|}{ Carbosulfan } & \multicolumn{2}{|l|}{ BPMC } & \multicolumn{2}{|l|}{ Permethrin } \\
\hline & $\mathrm{LD}_{50}$ & $\mathrm{LD}_{90}$ & $\mathrm{LD}_{50}$ & $\mathrm{LD}_{90}$ & $\mathrm{LD}_{50}$ & $\mathrm{LD}_{90}$ & $\mathrm{LD}_{50}$ & $\mathrm{LD}_{90}$ & $\mathrm{LD}_{50}$ & $\mathrm{LD}_{90}$ \\
\hline \multirow[t]{3}{*}{ N. lugens } & 10.00 & $3 9 \longdiv { 5 4 . 2 9 }$ & 0.63 & 227.60 & 0.13 & 23.50 & 3.75 & 80.13 & 66.25 & $23,812.40$ \\
\hline & $\mathrm{N}=500, \mathrm{n}=7$ & & $N=500, n=6$ & & $N=650, n=4$ & & $N=650, n=3$ & & $\mathrm{~N}=500, \mathrm{n}=5$ & \\
\hline & $X^{2}=13.50$ & $p<0.05$ & $X^{2}=73.53$ & $p>0.05$ & $X^{2}=29.49$ & $p>0.05$ & $X^{2}=41.13$ & $p>0.05$ & $X^{2}=7.32$ & $p<0.05$ \\
\hline \multirow[t]{3}{*}{ S. furcifera } & $\overline{7} .4 \overline{3}$ & 368.21 & $16 . \overline{43}$ & 722.86 & $1.0 \overline{7}$ & 67.86 & 2.14 & 461.79 & 0.36 & 147.50 \\
\hline & $\mathrm{N}=500, \mathrm{n}=4$ & & $N=500, n=4$ & & $\mathrm{~N}=500, \mathrm{n}=3$ & & $\mathrm{~N}=500, \mathrm{n}=2$ & & $\mathrm{~N}=500, \mathrm{n}=3$ & \\
\hline & $X^{2}=9.27$ & $p>0.05$ & $\mathrm{X}^{2}=6.28$ & $p<0.05$ & $X^{2}=42.40$ & $p>0.05$ & $X^{2}=31.85$ & $p>0.05$ & $X^{2}=6.60$ & $p<0.05$ \\
\hline \multirow[t]{3}{*}{ N. virescens } & $1.88^{-}$ & 165.13 & 5.13 & 224.13 & 0.25 & 5.08 & 0.25 & 44.75 & 0.63 & 34.38 \\
\hline & $\mathrm{N}=500, \mathrm{n}=4$ & & $N=500, n=4$ & & $\mathrm{~N}=500, \mathrm{n}=3$ & & $\mathrm{~N}=500, \mathrm{n}=2$ & & $\mathrm{~N}=500, \mathrm{n}=3$ & \\
\hline & $X^{2}=20.58$ & $\mathrm{p}>0.05$ & $X^{2}=8.35$ & $p<0.05$ & $X^{2}=72.17$ & $\mathrm{p}>0.05$ & $X^{2}=69.54$ & $p>0.05$ & $X^{2}=19.29$ & $p>0.05$ \\
\hline \multirow[t]{3}{*}{ C. spectra } & 0.17 & 6.79 & 0.29 & 2. 90 & $0 . \overline{02}$ & 1.71 & 0.14 & 14.35 & 0.02 & 0.31 \\
\hline & $\mathrm{N}=500, \mathrm{n}=3$ & & $\mathrm{~N}=500, \mathrm{n}=3$ & & $\mathrm{~N}=500, \mathrm{n}=2$ & & $\mathrm{~N}=500, \mathrm{n}=3$ & & $\mathrm{~N}=500, \mathrm{n}=3$ & \\
\hline & $X^{2}=40.12$ & $\mathrm{p}>0.05$ & $X^{2}=34.34$ & $p>0.05$ & $\mathrm{X}^{2}=1.88$ & $p<0.05$ & $X^{2}=42.76$ & $p>0.05$ & $X^{2}=11.51$ & $\mathrm{p}>0.05$ \\
\hline \multirow[t]{3}{*}{ L. oratorius } & 0.15 & 2708.74 & 0.17 & 161.20 & 0.03 & 3.86 & 0.09 & 89.51 & 0.11 & 3.86 \\
\hline & $\mathrm{N}=500, \mathrm{n}=3$ & & $\mathrm{~N}=500, \mathrm{n}=3$ & & $N=500, n=3$ & & $\mathrm{~N}=500, \mathrm{n}=3$ & & $\mathrm{~N}=500, \mathrm{n}=4$ & \\
\hline & $X^{2}=13.26$ & $p>0.05$ & $X^{2}=12.44$ & $p>0.05$ & $X^{2}=34.71$ & $p>0.05$ & $X^{2}=35.86$ & $p>0.05$ & $X^{2}=20.21$ & $p>0.05$ \\
\hline
\end{tabular}

Table 2: $\mathrm{LD}_{50}{ }^{*}$ and $\mathrm{LD}_{90}{ }^{* *}(\mu \mathrm{g} / \mathrm{g}$ insect body weight) values of insecticides for the predator populations at Batalagoda as determined by the topical application method.

\begin{tabular}{|c|c|c|c|c|c|c|c|c|c|c|}
\hline \multirow{2}{*}{ Species } & \multicolumn{2}{|l|}{ Dimethoate } & \multicolumn{2}{|l|}{ Chorpyrifos } & \multicolumn{2}{|l|}{ Carbosulfan } & \multicolumn{2}{|l|}{ BPMC } & \multicolumn{2}{|l|}{ Permethrin } \\
\hline & $\mathrm{LD}_{50}$ & $\mathrm{LD}_{90}$ & $\mathrm{LD}_{50}$ & $\mathrm{LD}_{90}$ & $\mathbf{L D}_{50}$ & $\mathrm{LD}_{90}$ & $\mathbf{L D}_{50}$ & $\mathrm{LD}_{90}$ & $\mathrm{LD}_{50}$ & $\mathrm{LD}_{90}$ \\
\hline \multirow[t]{3}{*}{ C. lividipennis } & 0.63 & 462.50 & 0.63 & 5.63 & 0.63 & 46.88 & 1.25 & 277.50 & 0.63 & 8.75 \\
\hline & $\mathrm{N}=250, \mathrm{n}=3$ & & $\mathrm{~N}=250, \mathrm{n}=3$ & & $N=250, n=2$ & & $\mathrm{~N}=250, \mathrm{n}=2$ & & $\mathrm{~N}=250, \mathrm{n}=3$ & \\
\hline & $X^{2}=30.11$ & $p>0.05$ & $X^{2}=5.65$ & $p<0.05$ & $X^{2}=1.15$ & $\mathrm{p}<0.05$ & $X^{2}=58.50$ & $p>0.05$ & $X^{2}=5.57$ & $p<0.05$ \\
\hline \multirow[t]{3}{*}{ M. discolor } & $0.90^{-}$ & 16.80 & 10.10 & 919.10 & 1.20 & 72.30 & 4.60 & 98.20 & 0.20 & 8.40 \\
\hline & $\mathrm{N}=350, \mathrm{n}=3$ & & $\mathrm{~N}=350, \mathrm{n}=3$ & & $\mathrm{~N}=350, \mathrm{n}=2$ & & $\mathrm{~N}=350, \mathrm{n}=3$ & & $\mathrm{~N}=350, \mathrm{n}=3$ & \\
\hline & $X^{2}=52.02$ & $p>0.05$ & $X^{2}=21.83$ & $p>0.05$ & $X^{2}=37.12$ & $p>0.05$ & $X^{2}=53.25$ & $\mathrm{p}>0.05$ & $X^{2}=30.25$ & $p>0.05$ \\
\hline \multirow[t]{3}{*}{$O$. indica } & $\overline{0.10}$ & 3.50 & 0.10 & 15.00 & 1.10 & $6 \overline{8} .80$ & 18.90 & $237.4 \overline{0}$ & 0.10 & 30.80 \\
\hline & $N=350, n=3$ & & $N=350, n=4$ & & $\mathrm{~N}=350, \mathrm{n}=2$ & & $\mathrm{~N}=350, \mathrm{n}=3$ & & $\mathrm{~N}=350, \mathrm{n}=3$ & \\
\hline & $X^{2}=4.75$ & $p<0.05$ & $X^{2}=64.93$ & $\mathrm{p}>0.05$ & $X^{2}=76.96$ & $p>0.05$ & $X^{2}=39.36$ & $p>0.05$ & $X^{2}=7.46$ & $\mathrm{p}<0.05$ \\
\hline \multirow[t]{3}{*}{ Tetragnatha sp. } & 2.67 & $23 \overline{55.33}$ & 1.11 & 22.44 & 62.89 & 6551.22 & 2.67 & 2693.56 & $\overline{0.22}$ & $10.1 \overline{1}$ \\
\hline & $\mathrm{N}=200, \mathrm{n}=3$ & & $\mathrm{~N}=200, \mathrm{n}=2$ & & $N=200, n=4$ & & $N=200, n=3$ & & $N=200, n=3$ & \\
\hline & $X^{2}=21.75$ & $p>0.05$ & $X^{2}=6.998$ & $p>0.05$ & $X^{2}=43.24$ & $p>0.05$ & $X^{2}=6.46$ & $p<0.05$ & $X^{2}=11.45$ & $p>0.05$ \\
\hline
\end{tabular}


Table 3: Percentage mortalties obtaned for Angunakolapuldssa insect populations ( $n=100)$

\begin{tabular}{|c|c|c|c|c|c|c|c|c|c|c|}
\hline \multirow{3}{*}{ Species } & \multicolumn{9}{|c|}{ Percentage mortalitres } & \\
\hline & \multicolumn{2}{|c|}{ Dimethoate } & \multicolumn{2}{|c|}{ Chlorpynfos } & \multicolumn{2}{|c|}{ Permethrin } & \multicolumn{2}{|c|}{ Carbosulfan } & \multicolumn{2}{|c|}{ BPMC } \\
\hline & A & B & A & B & A & B & A & B & $A$ & B \\
\hline$N$ lugens & 48 & $90 \overline{9}$ & 4686 & 7778 & 3738 & 65.81 & 51.22 & 8611 & 575 & 9535 \\
\hline$S$ furcifera & 5667 & 8444 & 444 & 7556 & 5556 & 89.09 & 50 & 90 & 5952 & 8333 \\
\hline$L$ oratorlous & 45 & 8167 & 5455 & 8722 & 9667 & 100 & 20 & 60 & 100 & 100 \\
\hline C lividipennis & 4737 & 681 & 5745 & 9375 & 50 & 90 & 60 & 88 & 5556 & 86 \\
\hline$M$ discolor & 5333 & 88 & 5385 & 769 & 9667 & 100 & 2727 & 92 & 40 & 8846 \\
\hline$O$ indeca & 50 & 9833 & 6833 & 85 & 4833 & 6833 & 45 & 85 & 5167 & 100 \\
\hline Tetragnatha sp & 55 & 85 & 95 & 100 & 100 & 100 & 80 & 95 & 5 & 60 \\
\hline
\end{tabular}

A - for the dosage, which gave $50 \%$ mortality of the same species at Batalagoda

B - for the dosage, which gave $90 \%$ mortality of the same species at Batalagoda.

Table 4: Percentage mortalities for the fixed dosages of 3,500 $\mu \mathrm{g} / \mathrm{g}$ DDT and 4,400 $\mu \mathrm{g} / \mathrm{g}$ malathion

\begin{tabular}{|c|c|c|c|c|}
\hline \multirow{2}{*}{ Species } & \multicolumn{2}{|c|}{$\begin{array}{l}\text { Percentage mortality for } \\
3500 \mu \mathrm{g} / \mathrm{g} \text { DDT }\end{array}$} & \multicolumn{2}{|c|}{$\begin{array}{l}\text { Percentage mortality for } \\
4400 \mu \mathrm{g} / \mathrm{g} \text { malathıon }\end{array}$} \\
\hline & Batalagoda & Angunakolapalassa & Batalagoda & Angunakolapalassa \\
\hline$N$ lugens & 80 & 8143 & 85 & 95 \\
\hline$N$ virescens & 75 & NT & 100 & NT \\
\hline$L$ oratorius & 50 & 3833 & 100 & 90 \\
\hline C spectra & 871 & NT & 9647 & NT \\
\hline$S$ furctfera & 56 & 9333 & 90 & 9667 \\
\hline C lividipennis & 100 & 9223 & 90 & 100 \\
\hline$M$ discolor & 554 & 1429 & 9634 & 9714 \\
\hline$O$ indica & 409 & 6222 & 65 & 74 \\
\hline Tetragnatha sp & 100 & 6429 & 95 & 6571 \\
\hline
\end{tabular}

$\mathrm{NT}=$ not tested

As the number of $N$. virescens and $C$. spectra were very low at Angunakolapalassa, the insecticide bioassays could not be carried out for these two species.

\section{RESULTS}

Log-probit mortality lines for dimethoate, chlorpyrifos, permethrin, carbosulfan and fenobucarb for the Batalagoda rice insect pest and predatory populations were plotted and $\mathrm{LD}_{50}$ and $\mathrm{LD}_{90}$ values estimated (Tables 1 and 2). Fitness of the log-probit mortality curves is given by the $\chi^{2}$ values and indicates whether the population showed a homogeneous $(\mathrm{p}<0.05)$ or a heterogeneous ( $p>0.05)$ response to the insecticide. These pest and predatory species from Angunakolapalassa were exposed to the insecticide dosages that resulted in $\mathrm{LD}_{50}$ and $\mathrm{LD}_{90}$ of the same insecticides from Batalagoda and the percentage mortalities obtained are given in Table 3.

Percentage mortalities of both Batalagoda and Angunakolapąlassa populations, when exposed to the fixed dosages of malathion and DDT, are given in Table 4. 
Table 5: Susceptible/ resistance status of rice insect pests and their predators to seven insecticides

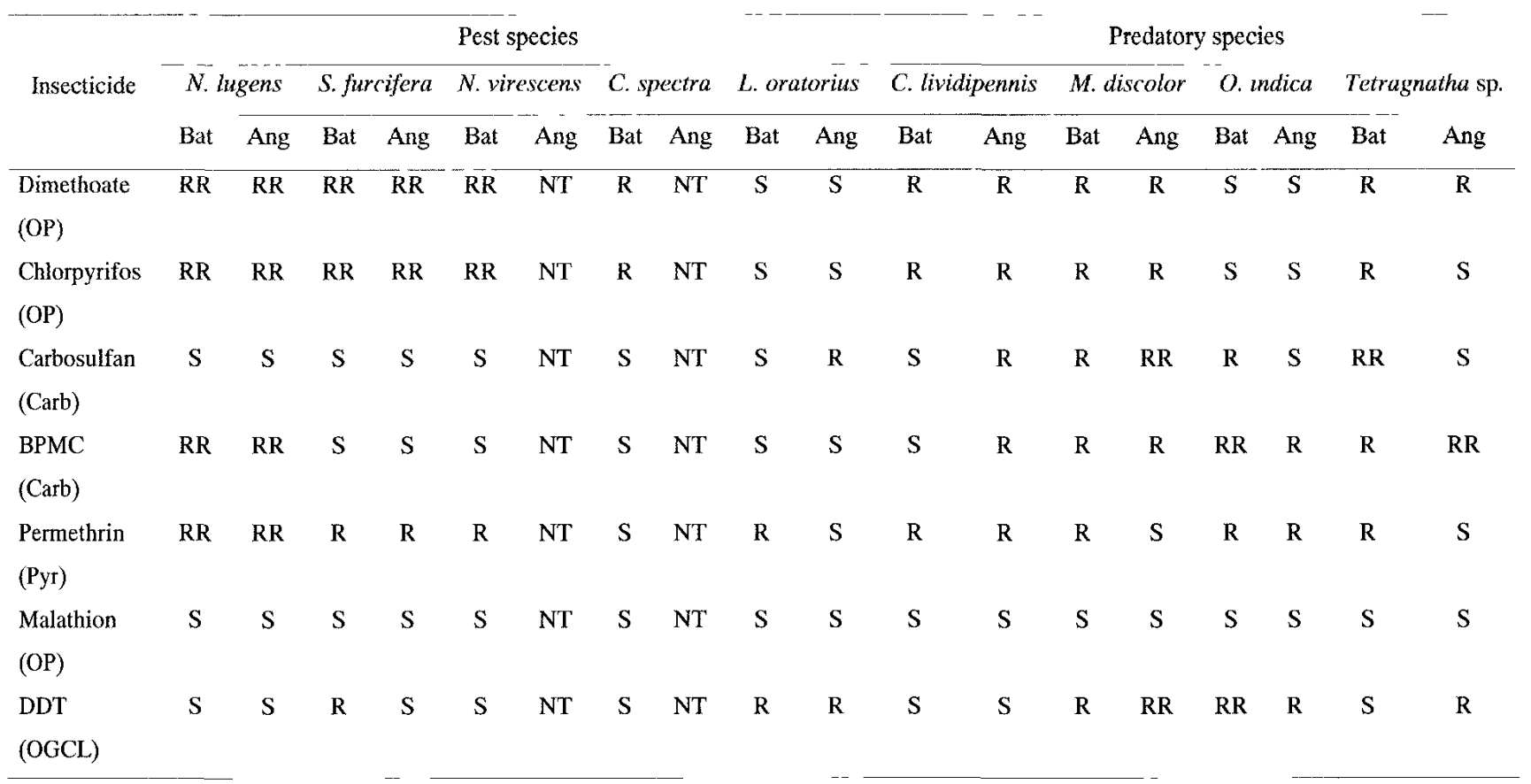

$\mathrm{OP}=$ organophosphate; $\mathrm{Carb}=$ carbomate $\mathrm{Pyr}=$ pyrethroid; $\mathrm{OGCL}=$ organochlorine; $\mathrm{RR}=$ highly resistant $\mathrm{R}=$ resistant $\mathrm{S}=$ susceptible;

NT $=$ not tested; Bat $=$ Batalagoda $;$ Ang $=$ Angunakolapalassa

According to all the bioassay results, comparative resistance/ susceptibility spectra were obtained for all the species and are presented in Table 5.

\section{DISCUSSION}

Large-scale use of synthetic insecticides was first started in Sri Lanka in 1945 with the introduction of organochlorines ${ }^{6}$. DDT and $\gamma$-BHC dust were heavily used in paddy cultivation until the mid 1970s ${ }^{7}$. DDT was introduced in 1957 and later it was replaced by malathion in $1975^{\circ}$. Usage of organophosphates such as malathion and fenitrothion in agriculture was legally restricted because of their important role in malaria control. Organochlorines were followed by carbamates, which was the major group of insecticides used in agriculture until the introduction of pyrethroids in 1994. In the health sector, malathion was the major insecticide of choice until the introduction of pyrethroids in early 1990s. However, it is still used in certain areas of the country in mosquito control activities.

At Batalagoda only paddy is cultivated while at Angunakolapalassa, pulses and cereals are also cultivated in addition to paddy. Insecticides, which are used to manage insect pests at both these sites, have been selected according to the pesticide recommendations of the Department of Agriculture. Most widely used insecticides are carbosulfan, fenobucarb, carbofuran, dimethoate, chlorpyrifos and these insecticides have been used for more than three decades.

Insecticide resistance can be assessed by a variety of bioassay methods i.e. direct application of insecticide droplets on to the insect body (topical application), insecticide impregnated paper method, spraying methods, leaf dip method, mixing insecticides with food etc. In the present study topical application method was used since it has been successfully used for rice insect pests, i.e. for the brown planthopper $N$. lugens ${ }^{9-15}$, the green leafhopper Nephotettix cincticeps $^{1,11,16,}$, the white-backed planthopper S. furcifer $a^{12,15}$ and for the small brown planthopper Laodelphax striatellus ${ }^{11}$. Other than rice insect pests, topical application method has been successfully used for other insects such as aphids and bruchid pests ${ }^{5,17-20}$.

Validity of the present results can be tested against available published data for some of these species. For carbosulfan susceptible populations of $N$. lugens and S.furcifera $\mathrm{LD}_{50}$ values have been reported as $5 \mu \mathrm{g} / \mathrm{g}$ and $3.5 \mu \mathrm{g} / \mathrm{g}^{15}$.During the present study Batalagoda populations of $N$. lugens, $S$. furcifera had $\mathrm{LD}_{50}$ values $0.13 \mu \mathrm{g} / \mathrm{g}$ and $1.07 \mu \mathrm{g} / \mathrm{g}$ respectively. Susceptible populations of $N$. lugens, $S$. furcifera and $N$. virescens have shown $L_{50}$ values of $0.02 \mu \mathrm{g} / \mathrm{g}, 2.9 \mu \mathrm{g} / \mathrm{g}$ and 2.77 $\mu \mathrm{g} / \mathrm{g}$ respectively for the insecticide fenobucarb ${ }^{11,14}$ 
These populations from Batalagoda had fenobucarb $L D_{50}$ values of $3.75 \mu \mathrm{g} / \mathrm{g}, 2.14 \mu \mathrm{g} / \mathrm{g}$ and $0.25 \mu \mathrm{g} / \mathrm{g}$ respectively. This comparison indicates that Batalagoda $N$. lugens population is highly resistant to fenobucarb while $S$. furcifera and $N$. virescens populations are susceptible. Present results show that the chlorpyrifos $\mathrm{LD}_{50}$ values ranged from 0.17 to $16.43 \mu \mathrm{g} / \mathrm{g}$ for rice pest species and from 0.10 to $10.10 \mu \mathrm{g} / \mathrm{g}$ for predatory species at Batalagoda. It has been reported that, for some of the vegetable insect pests, chlorpyrifos $\mathrm{LD}_{50}$ values ranged from 0.0013 to $5.3 \mu \mathrm{g} / \mathrm{g}^{20}$. Therefore, it appears that rice insects are more tolerant to chlorpyrifos than vegetable insects.

In general, $N$. lugens shows high resistance to several insecticides tested and there is no marked difference in resistance between the pest insect species and the predatory insects (Table 5). Apart from the concerns over the environment, DDT was abandoned in Sri Lanka due to the high resistance developed by insect populations. It appears that the overall resistance shown to DDT is decreasing in rice insects. It is therefore mportant to determine the underlying resistance mechanisms to these cross-resistance spectra.

\section{Acknowledgement}

This work was funded by the National Science Foundation of Sri Lanka Research Grant No. RG/99/B/01.

\section{References}

1. Hama H. \& Iwata T. (1978). Studies on the inheritance of carbamate-resistance in the Green rice leafhopper, Nephottix cincticeps Uhler (Hemiptera: Cicadellidae). Relationships between insensitivity of Acetylcholinesterase and crossresistance to carbamate and organophosphate insecticides. Applied Entomology and Zoology 13(3): 190-202.

2. Heinrchs E.A., Chelliah S., Valebcia S.L., Arceo M.B., Fabellar L.T., Aquino G.B. \& Pickin S. (1981). Manual for testing insecticides on rice. pp.15-23 International Rice Research Institute, Philippines.

3. Hideaki H. \& Kozaburo O. (1984). Electrophoretic esterase patterns in the brown planthopper, Nilaparvata lugens Stal (Hemiptera: Delphacidae) which developed resistance to insecticides. Applied Entomology and Zoology 19(1): 52-58.

4. Matsumara F. (1985). Toxicology of insecticides. p.598. Platinum Press, New York.

5. Bogamuwa M.M.S., Weerakoon K.C. \& Karunaratne S. H.P.P. (2002). Insecticide resistance in the Bruchid Callosobruchus maculatus, a storage pest of legumes. Ceylon Journal of Science (Biological Sciences) 30: 55-66.

6. Wickramasinghe M.B. (1981). Malaria and its control in Sri Lanka. Ceylon Medical Journal 26(3):107-115.

7. Fernandoo H.E. (1964). Insect Pests of Rice in Ceylon. Proceedings of a symposium. International Rice Research Institute Philippines, pp.575-789.
8. Herath P.R.J. \& Jayawardena K.G.I. (1988). DDT resistance in Anopheles culicifacies Giles and A. subpictus grassi (Diptera: Culicidae) from Sri Lanka: a field study on the mechanisms and changes in gene frequency after cessation of DDT spraying. Bulletin of Entomological Research 78: 717-723.

9. Aquino G.B. (1971). The detection and measurement of diazinon resistance in the brown planthopper, Nilaparvata lugens Stal. International Rice Research Insititute Saturday seminars, Philippines pp.1-5.

10. Nagata T., Masuda T. \& Moriya S. (1979). Devclopment of insecticide resistance in the brown planthopper Nilaparvata lugens Stal (Hemiptera: Delphacidae). Applied Entomology and Zoology 14(3): 264-269.

11. Ozaki K. (1980). Resistance of rice insect pest to insecticides in Japan. $16^{\text {th }}$ International Congress of Entomology, Kangawa Agriculture Experiment Station 9117, Fuchu-cho, Sakaide, Kagawa-Ken 762, Japan.

12. Nagata T. \& Masuda T. (1980). Insecticide susceptibility and wing-form ratio of the brown planthopper, Nilaparvata lugens (Stal) (Hemiptera: Delphacidae) and white-backed planthopper, Sogatella furcifera (Horvath) (Hemiptera: Delphacidae) of Southeast Asia. Applied Entomology and Zoology 15(1): 1019.

13. Hasuhi H. \& Ozaki K. (1981). Electophoretic esterase patterens in the brown planthopper, Nilaparvata lugens Stal (Hemiptera: Delphacidae) which developed resistance to insecticides. Applied Entomology and Zoology 19(1): 52-58.

14. Endo S., Masuda T. \& Kazano H. (1988a). Development and Mechanisms of Insecticide resistance in rice brown planthoppers selected with malathion and MTMC. Journal of Pesticide Science 13: 239-245.

15. Endo S., Nagata T., Kawabe S. \& Kazano H. (1988b). Changes of insecticide susceptibility of the white-backed planthopper Sogatella furcifera HORVATH (Homoptera: Delphacidae) and the brown planthopper Nilaparvata lugens Stal. (Homptera: Delphacidae). Applied Entomology and Zoology 23(4): 417-421.

16. Miyata T., Sakai H., Saito T., Yoshioka K., Ozaki K., Sasaki Y. \& Tsuboi A. (1981). Mechanism of joint toxic action of kitazin $P$ with malathion in the malathion resistant green rice leafhopper, Nephotettix cincticeps Uhler (Hemiptera: Delphacidae). Applied Entomology and Zoology 16(3):258-263.

17. Beranek A.P. (1974). Esterase variation and organophosphate resistance in populations of Aphis fabae and Myzus persicae. Entomologia Experimentalis et Applicata 17:129-142.

18. Needham P.H. \& Devonshire A.L. (1975). Resistance to some organophosphrous insecticides in field populations of Myzus persicae from sugarbeet in 1974. Pesticide Science 6: $547-551$

19. Rani P.U. \& Jamil K. (1989). Effect of water hyacinth leaf extraction on mortality, growth and metamorphosis of certain pests of stored products. Insect Science and its Application 10(3): 327-332.

20. Damayanthi B.T. \& Karunaratne S.H.P.P. (2005). Biochemical characterisation of insecticide resistance in vegetable insect pests and predatory ladybird beetles. Journal of the National Science Foundation of Sri Lanka 33(2):115-122. 